\title{
Crude Oil Removal using Calotropis procera
}

\author{
Raoni Batista dos Anjos, ${ }^{\text {a,* }}$ Larissa Sobral Hilário, ${ }^{\mathrm{a}}$ Henrique Borges de Moraes \\ Juviniano, ${ }^{a}$ and Djalma Ribeiro da Silva ${ }^{\text {a,b }}$
}

\begin{abstract}
Calotropis procera (CP) fiber is a natural and renewable material with great lumen and hydrophobic-oleophilic characteristics, providing it with a good oil absorption capacity. In order to increase the absorption efficiency of organic oils and solvents, CP fiber was treated with either $0.1 \mathrm{M} \mathrm{NaOH}$ $(\mathrm{CPNaOH}), 1 \% \mathrm{NaClO}_{2}\left(\mathrm{CPNaClO}_{2}\right)$, or hydrothermal conditions $(\mathrm{CPHT})$ in an effort to improve its ability to remove crude oil from leaks or spills. The fibers were characterized by Fourier transform infrared spectroscopy (FTIR), scanning electron microscopy with field emission (SEM-FEG), and wettability for water and diesel. The fibers $\mathrm{CPHT}, \mathrm{CPNaOH}$, and $\mathrm{CPNaClO} 2$ showed excellent hydrophobic-oleophilic properties and good crude oil absorption capacity in water $99.2 \mathrm{~g} / \mathrm{g}, 103.9 \mathrm{~g} / \mathrm{g}$, and $92.0 \mathrm{~g} / \mathrm{g}$. The absorption after 60 min for most fibers in dry systems or with a layer of oil floating on water exceeded $90 \%$ of its absorption capacity for the time of $1440 \mathrm{~min}$. The $\mathrm{CPNaOH}$ after 6 runs absorbed $445.8 \mathrm{~g}$ of crude oil per gram of fiber. Based on the results, the treated fibers can be considered an alternative for the removal of oil from leaks and spills due to the high availability and excellent absorption property for various oils.
\end{abstract}

Keywords: Calotropis procera; Absorption; Crude oil

Contact information: a: Postgraduate Program in Petroleum Science and Engineering of the Federal University of Rio Grande do Norte, Av. Sen. Salgado Filho, 3000 - Lagoa Nova, CEP: 59072-970 Natal/RN, Brazil; b: Institute of Chemistry of the Federal University of Rio Grande do Norte, Av. Sen. Salgado Filho, 3000 - Lagoa Nova, CEP: 59072-970 - Natal/RN, Brazil;

*Corresponding author: raonianjos@gmail.com

\section{INTRODUCTION}

Crude oil is a natural resource that was formed millions of years ago. When produced, transported, and stored, there is an imminent risk of causing significant impacts (Paul et al. 2013). The spillage of oil and its derivatives in water has been a challenge in the world due to the high toxicity and mobility of hydrocarbons. Its presence in the environment may cause continuous contamination by monoaromatic hydrocarbons, aromatic polycyclic hydrocarbons (HPA), and total petroleum hydrocarbons (TPH), as well as generating problems for several years or decades (Rengasamy et al. 2011). This is due to the chemical and physical properties of the oil being altered by "weathering," such as evaporation, dissolution, microbial degradation, dispersion, and adsorption in suspended materials and photochemical oxidation (Rengasamy et al. 2011; Paul et al. 2013; Gros et al. 2014; Zengel et al. 2016). Therefore, it is important to develop efficient and economically feasible technologies to remove oil hydrocarbons and their derivatives after these accidents (AlAmeri et al. 2019).

The mechanical removal of oils in water by sorbent materials can be a very efficient technique (Mysore et al. 2005). The characteristics to determine a good oil sorbent include hydrophobicity, oleophillicity, high sorption capacity, fast kinetics of sorption, reuse, and 
biodegradability (Prince 2015). The effectiveness of any cleaning technology depends on the individual circumstances of spillage (location, oil type, amount of oil) and also unpredictable variables such as climate (Wahi et al. 2014). Among the techniques available for the removal of oil from water, the physical method using sorbents can be one of the most efficient techniques (Pintor et al. 2016; van Gelderen et al. 2017).

A wide range of sorbent materials has been reported (Wahi et al. 2014; Sabir 2015; Pintor et al. 2016; van Gelderen et al. 2017; Hilário et al. 2019), which distribute mainly in three classes: inorganic, synthetic polymers, and natural. Inorganic sorbents are composed of materials such as vermiculite, zeolite, silica, and perlite (Mysore et al. 2005; Bastani et al. 2006; Zadaka-Amir et al. 2013; Yu et al. 2017). Their performance is limited by low oil sorption capacity, oil-water selectivity, inadequate buoyancy, and nonbiodegradability. Synthetic polymers including materials such as polyurethane sponges, polypropylene fibers, and polystyrene fibers (Ke et al. 2014; Renuka et al. 2015; Wu et al. 2015; Saleem et al. 2018) have shown high absorption and recyclability capacity and are commonly marketed for sorption in oil spills due to their high hydrophobicities. These sorbents are efficient; however, they are not biodegradable, which is a great disadvantage. However, the application of organic natural materials derived from plant sources such as rice husk, sawdust, cotton fiber, kapok fiber, and cattail fibers (Adebajo and Frost 2004; Lim and Huang 2007a; Lim and Huang, 2007b; Wang et al. 2013a; Wang et al. 2013b; Ge et al. 2016; Ma et al. 2016) have been studied for application in cleaning in oil spills due to their environmentally friendly characteristics, low cost, easy availability, and biodegradability (Ge et al. 2016). Hubbe et al. (2013) in their review showed that natural cellulose-based fibers can be used as oil sorbents. Encouraging results have been found with similar or even greater capacity to sorb oil from the water surface when compared to typical polypropylene (PP) products that have been used more frequently for this purpose. Moreover, a variety of effective cellulosic materials have been demonstrated for spraying hydrocarbon oils, especially in the absence of water, and their performances in the presence of water can be improved by several pretreatments that make them more hydrophobic (Hubbe et al. 2013).

Calotropis procera fiber (CP), from the family Apocynaceae, has a natural wax coating on its surface and lumens (void central space) even larger than the kapok fiber (Thilagavathi et al. 2018). CP fiber has oleophilic, hydrophobic characteristics with high sorbent capacity for several oils; it shows greater than 50\% re-sorption after 6 reuse cycles (Nascimento et al. 2016; Thilagavathi et al. 2018; Hilário et al. 2019). Thus, it is an excellent alternative for leakage and cleaning an oil spill from the water surface.

To improve the oil sorption properties of natural fibers, they can be modified by (1) chemical treatment, using alkalis/acid, solvent treatment, oxidation treatment, and acetylation (Abdullah et al. 2010; Liu and Wang 2011; Liu et al. 2012; Wang et al. 2012; Wang et al. 2013c) and (2) physical treatments such as hydrothermal, radiation, and ultrasonic (Liu et al. 2012; Tang et al. 2012; Zhang et al. 2014). These modifications can be used to develop materials with new hydrophobic-oleophilic characteristics and high oil sorption capabilities (Husseien et al. 2008; Razavi et al. 2015; Zheng et al. 2015; Anuzyte and Vaisis 2018).

The objective of the present work was to modify the fiber with solutions of $\mathrm{NaOH}$, $\mathrm{NaClO}_{2}$, and hydrothermal treatment to alter the surface, surface wax, and hollow structure of the fiber. The effects of treatments on crude oil absorption were evaluated and compared with $\mathrm{CP}$ in natura. Considering the high performance of $\mathrm{CP}$, its low value, the abundance 
of raw materials, and easy synthesis methods, the resulting fibers are promising approaches for cleaning and removing a variety of oils from the water surface.

\section{EXPERIMENTAL}

\section{Materials}

The Calotropis procera $(\mathrm{CP})$ fruits were collected in the municipality of Natal (latitude $5^{\circ} 44^{\prime} 31.00^{\prime \prime S}$ and longitude $35^{\circ} 12^{\prime} 18.98^{\prime \prime W}$ ), Rio Grande do Norte state, Brazil, and the $\mathrm{CP}$ fibers were collected and manually separated from the seeds, being dried at room temperature $\left(25 \pm 1{ }^{\circ} \mathrm{C}\right.$ ) for $24 \mathrm{~h}$. For the absorption tests, crude oil (viscosity $=73.6$ $\mathrm{cP}$ and density at $20^{\circ} \mathrm{C}=861.0 \mathrm{~kg} / \mathrm{m}^{3}$ ) classified as medium, ${ }^{\circ}$ API grade 31.29 , and marine diesel (viscosity $=2.789 \mathrm{cP}$ and density at $20{ }^{\circ} \mathrm{C}=827.9 \mathrm{~kg} / \mathrm{m}^{3}$ ), was provided by PETROBRAS, Guamaré Pole, Rio Grande do Norte, Brazil. New (viscosity $=62.73 \mathrm{cP}$ and density at $20{ }^{\circ} \mathrm{C}=850.0 \mathrm{~kg} / \mathrm{m}^{3}$ ) and used engine lubricant (viscosity $=69.25 \mathrm{cP}$ and density at $20{ }^{\circ} \mathrm{C}=854.0 \mathrm{~kg} / \mathrm{m}^{3}$ ) were purchased from the local market, Natal, Rio Grande do Norte state, Brazil. The diesel oil (viscosity $=1.953 \mathrm{cP}$ and density at $20{ }^{\circ} \mathrm{C}=813$ $\mathrm{kg} / \mathrm{m}^{3}$ ) was acquired from a gas station located in the city of Natal, Rio Grande do Norte, Brazil. Distilled water was produced in the laboratory, while the methyl blue used to dye the distilled water in the selectivity test was acquired from Neon, Suzano, São Paulo, Brazil. The sodium hydroxide Pa ACS $(\mathrm{NaOH})$ was acquired from Vetec, Sigma Aldrich, Duque de Caxias, Rio de Janeiro, Brazil. Sodium chlorite PA ACS $\left(\mathrm{NaClO}_{2}\right)$ was obtained from Sigma Aldrich Brazil, São Paulo, Brazil. The Benzene PA (viscosity $=0.484 \mathrm{cP}$ and density at $20{ }^{\circ} \mathrm{C}=808.0 \mathrm{~kg} / \mathrm{m}^{3}$ ) was acquired from Neon, Suzano, São Paulo, Brazil.

\section{Methods}

Fiber treatment

Three processes of treatment of fibers in natura were performed. The first consisted of hydrothermal treatment in water (CPHT), with the immersion of $2 \mathrm{~g}$ of fiber in $400 \mathrm{~mL}$ of heated water at $80{ }^{\circ} \mathrm{C}$ with agitation for $1 \mathrm{~h}$ (Selvam and Santiago 2007). The second treatment submerged the fiber in $400 \mathrm{~mL}$ of $\mathrm{NaOH} 0.1 \mathrm{M}$ solution $(\mathrm{CPNaOH})$ with agitation for $1 \mathrm{~h}$ (Wang et al. 2012), and in the last treatment, $2 \mathrm{~g}$ of the fiber was placed in $400 \mathrm{~mL}$ of $\mathrm{NaClO}_{2}$ solution $1 \%\left(\mathrm{CPNaClO}_{2}\right)$ with agitation for $1 \mathrm{~h}$ at $80{ }^{\circ} \mathrm{C}$, after which the fibers were washed with distilled water and were then subjected to kiln drying (Huang and Lim 2006). At the end of the treatments, all fibers were oven-dried for $24 \mathrm{~h}$ at $105^{\circ} \mathrm{C}$ $\left( \pm 2{ }^{\circ} \mathrm{C}\right)$. The treated fibers were stored in high-density polyethylene (HDPE) containers and labeled.

\section{Characterization}

The FTIR spectra of fibers were performed in a Frontier instrument (Perkin Elmer, Waltham, MA, USA) from 400 to $4000 \mathrm{~cm}^{-1}$, with a resolution of $4 \mathrm{~cm}^{-1}$. The morphologies of the fiber surfaces were characterized in a scanning electron microscope with field emission (SEM-FEG), Zeiss Auriga 40 (Zeiss, Oberkochen, Germany), with a power of 15 $\mathrm{kV}$. The fibers were coated with gold film. The surface wettability to water and oil of fibers was evaluated using a Tensiometer, model K100C (Krüss, Hamburg, Germany).

For oils (crude oil, diesel, marine diesel, new and used engine lubricant, as well as benzene) density was determined using the digital densimeter, model DMA 5000M (Anton Paar, Graz, Austria, Europe) while the viscosity was determined using a rheometer, model 
MCR 302 (Anton Paar, Graz, Austria, Europe).

\section{Measurements of oil absorption capacity}

The fiber absorption potential was determined based on the method reported by Hilário et al. (2019). The absorption capacity was tested for three systems: crude oil alone (Dry), crude oil as a layer on water, simulating an oil spill on the surface of the water (Layer), and water alone. The absorption capacity was tested for three systems: crude oil (Dry), crude oil and water (Layer), and water. Fibers were immersed into the three systems at room temperature $\left(25^{\circ} \mathrm{C} \pm 2{ }^{\circ} \mathrm{C}\right)$ during different time intervals, from 5 to $1440 \mathrm{~min}$. The swollen fibers were removed and drained on a stainless steel screen and weighed. The absorption capacity (g/g), S, was calculated according to Eq. 1 (Hilário et al. 2019),

$$
S=\left(W_{f}-W_{i}\right) / W_{i}
$$

where $W_{i}(\mathrm{~g})$ and $W_{f}(\mathrm{~g})$ are the mass before and after absorption, respectively.

\section{Reusability}

The reuse of the fibers was evaluated by simple compression; $10 \mathrm{mg}$ of the sample was immersed in $5 \mathrm{~mL}$ of crude oil for $60 \mathrm{~min}$ at room temperature. The fibers were compressed with tweezers, and the resorption capacity was calculated as the ratio of the resorption mass to the initial absorption mass (Hilário et al. 2019).

\section{Determination of oil-water selectivity/wettability mobility}

The fibers were fixed at the bottom of two beakers with double-sided adhesive tape to evaluate the fibers' oil-water selectivity (Zheng et al. 2017). Approximately $100 \mathrm{~mL}$ of common diesel and $100 \mathrm{~mL}$ of distilled water with dye (methyl blue) were added. Pictures were taken using a digital camera.

\section{RESULTS AND DISCUSSION}

\section{Characterization}

FTIR spectra

To evaluate the treatments of $\mathrm{CP}$ fiber with $\mathrm{NaOH}, \mathrm{NaClO}_{2}$ and hydrothermal treatment, the fibers were analyzed by FTIR spectroscopy (Fig. 1). The CP absorption peaks at $3339 \mathrm{~cm}^{-1}, 2920 \mathrm{~cm}^{-1}, 1734 \mathrm{~cm}^{-1}, 1368 \mathrm{~cm}^{-1}, 1244 \mathrm{~cm}^{-1}$, and $1032 \mathrm{~cm}^{-1}$ were characteristic of Calotropis procera (Hilário et al. 2019). When comparing the spectra of Calotropis procera fiber nontreated, $\mathrm{CPNaClO}_{2}$, and $\mathrm{CPNaOH}$, the following results were obtained: a decrease in the intensity of functional groups, including $\mathrm{C}-\mathrm{H}\left(2920 \mathrm{~cm}^{-1}\right), \mathrm{C}=\mathrm{O}$ $\left(1734,1368\right.$, and $\left.1244 \mathrm{~cm}^{-1}\right)$, and C-O $\left(1032 \mathrm{~cm}^{-1}\right)$ (Zheng et al. 2017). According to Tu et al. (2018), this is also concerned with the removal of wax, pectin, and other substances on the surface of the fiber (Lv et al. 2017). As observed by Draman et al. (2014), attenuations or disappearance of the near peaks corresponding to lignin $\left(1505\right.$ and $\left.1597 \mathrm{~cm}^{-1}\right)$ and hemicellulose (1737 and $1248 \mathrm{~cm}^{-1}$ ) were observed. Such attenuations or disappearances may be related to partial removal of the wax layer from its surface (Mwaikambo and Ansell 2002; Fan et al. 2012; Wang et al. 2013b). Based on the FTIR spectrum results for $\mathrm{CPNaOH}$ and $\mathrm{CPNaClO}_{2}$, the removal of wax, lignin, and hemicelluloses was successful (Draman et al. 2014).

For the hydrothermally treated sample (CPHT), there was no obvious variation in other bands except the changes mentioned above. 


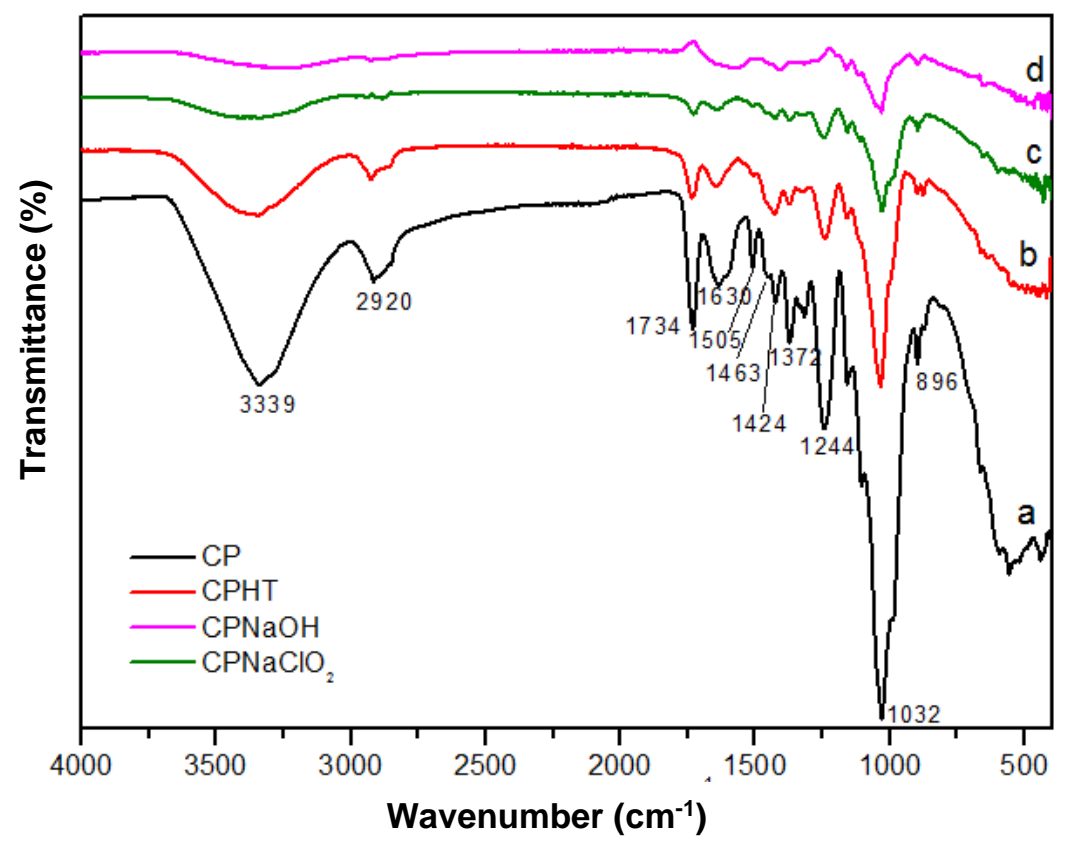

Fig. 1. FTIR spectra of (a) $\mathrm{CP}$, (b) $\mathrm{CPHT}$, (c) $\mathrm{CPNaClO}_{2}$, and (d) $\mathrm{CPNaOH}$

\section{Morphological Analysis - SEM}

Figure 2 shows micrographs of $\mathrm{CP}$ fibers in natura and treated $(\mathrm{CPHT}, \mathrm{CPNaOH}$, and $\mathrm{CPNaClO}_{2}$ ). There were hollow structures in the longitudinal and cross-fiber images, which enables the fixation of the oil and the trap of inter- and intra-fiber structures (van Gelderen 2017) This microstructure aids the buoyancy, as the interior spaces are filled with air.

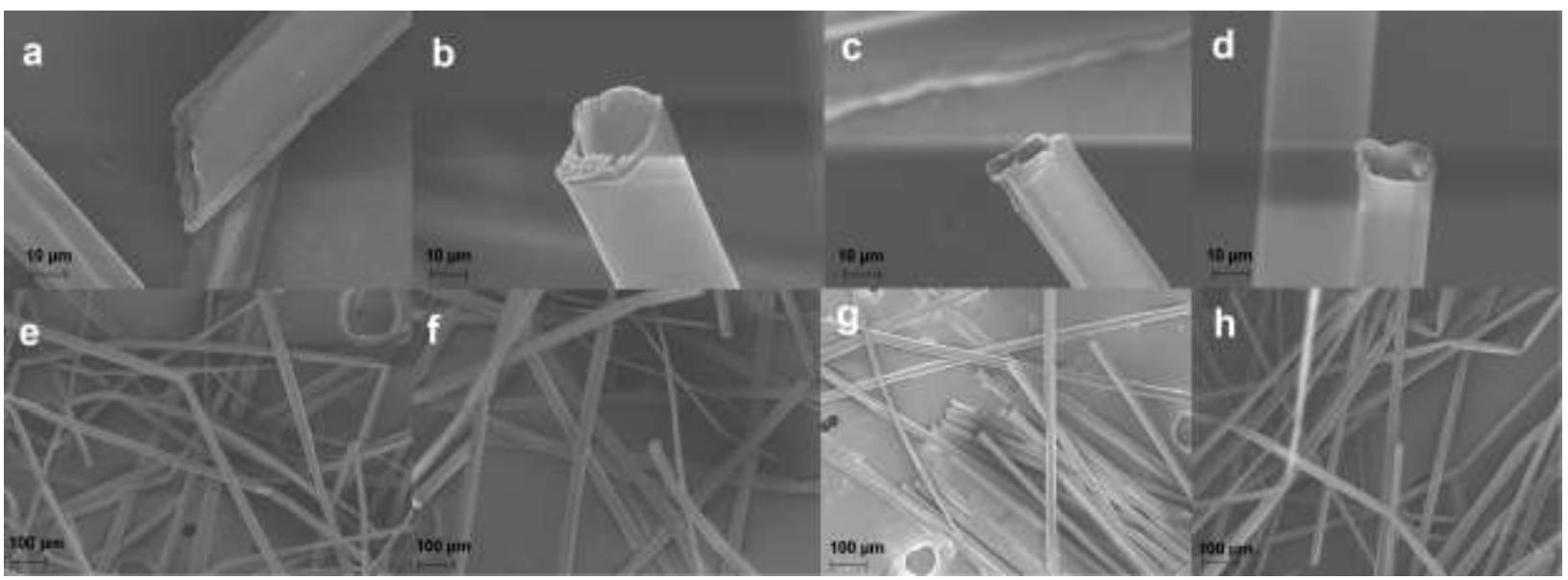

Fig. 2. Micrographs obtained by the SEM-FEG $1000 \times$ (a) CPHT, (b), $\mathrm{CPNaOH}$, (c) $\mathrm{CPNaClO}_{2}$, and (d) $\mathrm{CP} ; 100 \times$ (d) $\mathrm{CPHT}$, (e) $\mathrm{CPNaOH}$, (f) $\mathrm{CPNaClO}_{2}$, and (h) $\mathrm{CP}$

The micrographs (Fig. 2a-d) show a slick surface with hydrophobic waxy coating inside the hollow structure (Nascimento et al. 2016; Hilário et al. 2019; Song et al. 2019). However, no difference was observed on the surface of the treated fibers (Song et al. 2019), except in $\mathrm{CPNaClO}_{2}$ fiber, where a flattening was observed after the removal of wax and other extractives. Zhang et al. (2014) report the appearance of small debris on the surface 
of the Populus fiber, attributed to the dissolution of hemicellulose traces and lignin caused by hydrothermal treatment. Wang et al. (2012) found that natural fibers, when treated with $\mathrm{NaOH}$, present broken holes and shallow grooves on the surface of their fibrils. Yi et al. (2018) compared the tubular structure of Calotropis gigantea fiber with $\mathrm{NaClO}_{2}$ to remove part of the wax, resulting in a smoother surface, and also a hollow structure with thin walls. In general, the fibers treated with solution enable the surface to increase and improve oil adhesion to facilitate its entry into the lumen, thus ensuring a high oil absorption capacity.

The diameter, wall thickness, cross-sectional area, and percentage of void fiber space were determined using the Image-J software, from the micrographs of SEM-FEG (Fig. 2e-h) (Thilagavathi et al. 2018; Hilário et al. 2019). For the calculation of the diameter, 10 measurements of fiber diameters were performed, and the mean and standard deviation was calculated. The results are reported in Table 1.

Table 1. Morphological Details of the Various Fibers

\begin{tabular}{|c|c|c|c|c|}
\hline Fiber & Diameter $(\mu \mathrm{m})$ & $\begin{array}{c}\text { Cell Wall Thickness } \\
(\mu \mathrm{m})\end{array}$ & Void $(\%)$ & $\begin{array}{c}\text { Specific Surface } \\
\text { Area }\left(\mathrm{m}^{2} / \mathrm{kg}\right)\end{array}$ \\
\hline $\mathrm{CPNaOH}$ & $37.47 \pm 3.80$ & 0.633 & 93 & 390.8 \\
\hline $\mathrm{CPHT}$ & $24.56 \pm 4.13$ & 0.455 & 93 & 161.6 \\
\hline $\mathrm{CPNaClO}{ }_{2}$ & $27.14 \pm 3.55$ & 0.598 & 91 & 100.6 \\
\hline $\mathrm{CP}$ & $23.84 \pm 4.44$ & 0.520 & 91 & 146.6 \\
\hline
\end{tabular}

The nontreated fiber (CP) had an average diameter of $23.84 \pm 4.44 \mu \mathrm{m}$, a result similar to the work of Thilagavathi et al. (2018) which was $24.70 \mu \mathrm{m}$. The fibers treated with $\mathrm{CPHT}, \mathrm{CPNaOH}$, and $\mathrm{CPNaClO}_{2}$ had diameters greater than $\mathrm{CP}$, being $24.56 \pm 4.13$ $\mu \mathrm{m}, 37.47 \pm 3.80 \mu \mathrm{m}$, and $27.14 \pm 3.55 \mu \mathrm{m}$, respectively. In addition, the $\mathrm{CPNaOH}$ presented the largest diameter. Similarly, this fiber presented a larger specific surface area of $390.8 \mathrm{~m}^{2} / \mathrm{kg}$, followed by $\mathrm{CPHT}, \mathrm{CP}$, and $\mathrm{CPNaClO}_{2}$. The small surface area of the $\mathrm{CPNaClO}_{2}$ fiber can be attributed to the shape of the hollow fiber with the presence of flattened/collapsed lumen (Fig. 2f). The highest percentage of voids was associated with $\mathrm{CPNaOH}$ and $\mathrm{CPHT}$ fibers, which was $93 \%$ hollow lumen, followed by $\mathrm{CP}$ and $\mathrm{CPNaClO}_{2}$ fibers.

\section{Oil-absorption capacities}

The results of the oil absorption tests are presented in Fig. 3, varying the contact time $(5,20,40,60$, and $1440 \mathrm{~min}$.). As expected, the absorption increased with time Anunciado et al. (2005). Because the CP fiber has large lumens coated with wax, it has high dry sorption capacity for oil between 48.6 and $74.0 \mathrm{~g} / \mathrm{g}$, according to Hilário et al. (2019). Anunciado et al. (2005) obtained similar results in the sorption tests with the increase in the contact time of the oil with the sorbent. The contact time of $24 \mathrm{~h}$ (1440 min) presented the highest absorption capacity for crude oil (Fig. 3a).

Removing part of the hydrophobic wax from the surface through hydrothermal treatment and chemical treatment using $\mathrm{NaOH}$ and $\mathrm{NaClO}_{2}$ was proposed to improve the absorption capacity of crude oil. The dry absorption capacity for the CPHT, $\mathrm{CPNaOH}$, and $\mathrm{CPNaClO}_{2}$ treated fibers increased by $27.0 \%, 32.2 \%$, and $21.7 \%$, respectively, when compared to the untreated $\mathrm{CP}$ fiber. The $\mathrm{CPNaOH}$ presented the highest sorption capacity, $97.9 \mathrm{~g} / \mathrm{g}$, followed by CPHT, and $\mathrm{CPNaClO}_{2}$ with $94.0 \mathrm{~g} / \mathrm{g}$ and $90.1 \mathrm{~g} / \mathrm{g}$, respectively, highlighting the absorption capacity and oleophobicity of the fibers. In addition, the treatments increased the diameters (Table 1), consequently, increasing the potential of oil 
absorption. The fiber treated with $\mathrm{NaOH}$ presented a higher absorption capacity of crude oil $(97.87 \mathrm{~g} / \mathrm{g})$, which may be related to the $57 \%$ increase in the diameter and percentage of empty spaces when compared to CP. Huang and Lim (2006) found that Sumaúma fiber treatment with $\mathrm{NaClO}_{2}$ removed part of lignin, increasing the absorption capacity of various solvents. Zhang et al. (2014) observed an increase in oil absorption capacity by dissolving hemicellulose and deposition of lignin droplets by hot water. In addition, hydrothermal treatment greatly increased the surface area of cellulose, observed for CPHT.
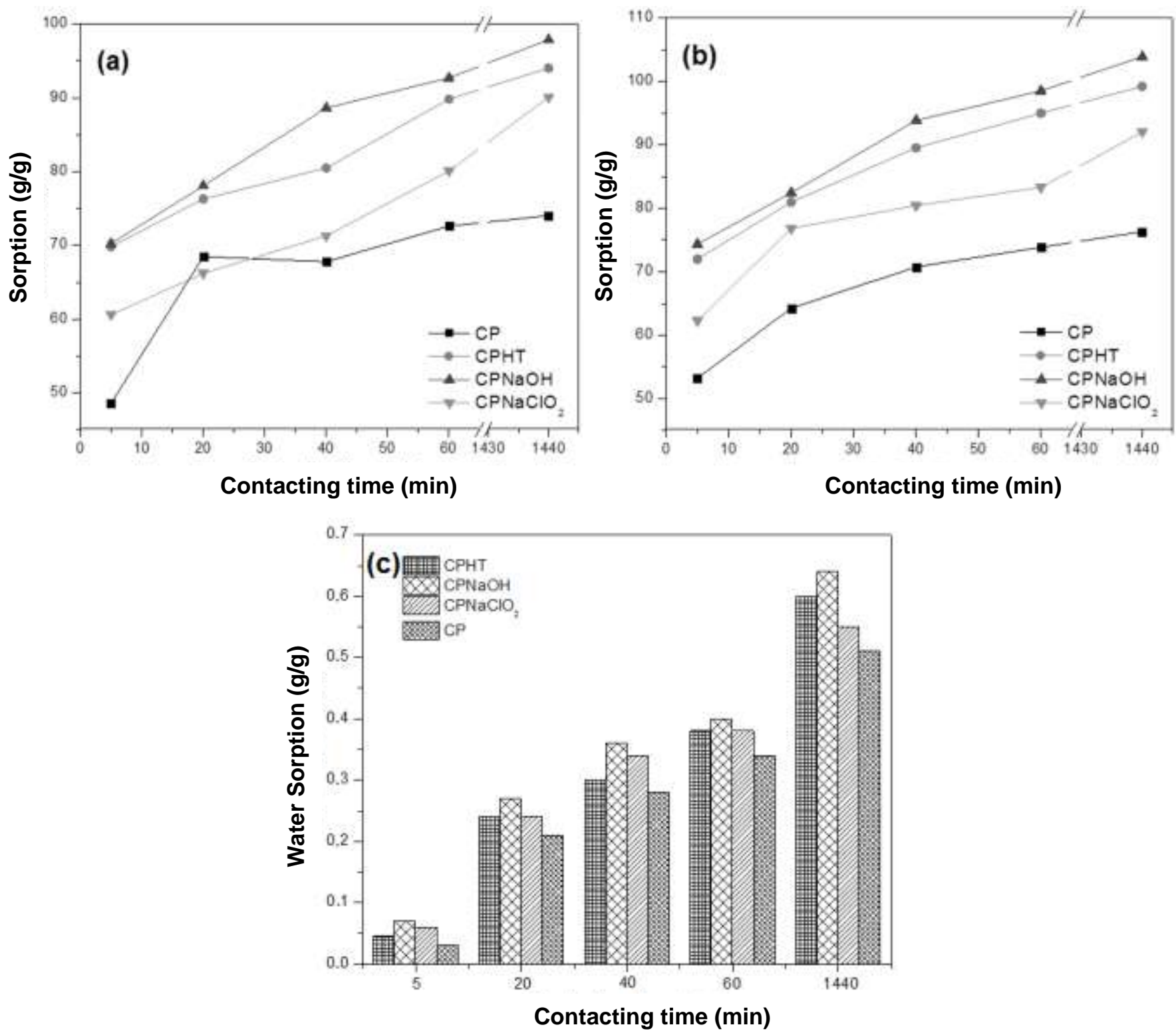

Fig. 3. Absorption test with crude oil (a) dry, (b) oil layer on water, and (c) water sorption

A commonly reported disadvantage of using plant fibers as sorbents in an aqueous medium is the high water sorption (Annunciado et al. 2005). However, in the present study, the amount of water sorbed in relation to the crude oil was negligible, showing the hydrophobic and oleophilic character of $\mathrm{CP}, \mathrm{CPHT}, \mathrm{CPNaOH}$, and $\mathrm{CPNaClO}_{2}$ fibers. As observed in Fig. 3c, CPHT, $\mathrm{CPNaOH}$, and $\mathrm{CPNaClO}_{2}$ fibers absorbed more water when 
compared to $\mathrm{CP}$ in natura, possibly by removing part of the waxy material from the $\mathrm{CP}$ surface. The water sorption for the $\mathrm{CP}, \mathrm{CPHT}, \mathrm{CPNaOH}$, and $\mathrm{CPNaClO}_{2}$ ranged from 0.03 to $0.64 \mathrm{~g} / \mathrm{g}$, suggesting a high hydrophobicity of the treated fibers. In addition, as expected, water sorption also increased over time, and all water sorption values were subtracted from the results of the layer tests.

Table 2. Absorption Percentage for the Several Contact Times in Relation to the Time 1140 min for the Dry and Layer Systems

\begin{tabular}{|c|c|c|c|c|c|}
\hline System & $\begin{array}{c}\text { Contact Time } \\
(\mathrm{min})\end{array}$ & $\mathrm{CP}$ & $\mathrm{CPHT}$ & $\mathrm{CPNaOH}$ & $\mathrm{CPNaClO}_{2}$ \\
\hline \multirow{4}{*}{ Dry } & 5 & $66 \%$ & $74 \%$ & $72 \%$ & $67 \%$ \\
\cline { 2 - 6 } & 20 & $92 \%$ & $81 \%$ & $80 \%$ & $74 \%$ \\
\cline { 2 - 6 } & 40 & $92 \%$ & $86 \%$ & $91 \%$ & $79 \%$ \\
\cline { 2 - 6 } & 60 & $98 \%$ & $96 \%$ & $95 \%$ & $89 \%$ \\
\hline \multirow{4}{*}{ Layer } & 1440 & $100 \%$ & $100 \%$ & $100 \%$ & $100 \%$ \\
\cline { 2 - 6 } & 5 & $70 \%$ & $73 \%$ & $72 \%$ & $68 \%$ \\
\cline { 2 - 6 } & 20 & $84 \%$ & $82 \%$ & $79 \%$ & $83 \%$ \\
\cline { 2 - 6 } & 40 & $93 \%$ & $90 \%$ & $90 \%$ & $91 \%$ \\
\hline
\end{tabular}

Table 2 shows the percentage of absorption reached by several contact times in relation to the maximum absorption after $1440 \mathrm{~min}(24 \mathrm{~h})$ for dry and layer systems. For the dry system, $65 \%$ of the absorption capacity for the time of 1440 min was accumulated during the first five minutes, remaining in an interval between $66 \%$ and $74 \%$. According to Annunciado et al. (2005), most absorption occurs in the first minutes for the studied fibers, followed by a slow increase in the absorption values over time, i.e., much of the absorption potential of the fibers is achieved in a short interval of time. Most of the fibers used in this work reached at least $90 \%$ of their maximum absorption capacity in 60 min, except for the $\mathrm{CPNaClO}_{2}$, which was $88.9 \%$. In total, regardless of absorption conditions (dry or layer), the test at an absorption time of $24 \mathrm{~h}$ showed an absorption capacity of 76.3 $\mathrm{g} / \mathrm{g}$ for the CP wire (Hilário et al. 2019), $99.2 \mathrm{~g} / \mathrm{g}$ for CPHT, $103.9 \mathrm{~g} / \mathrm{g}$ for $\mathrm{CPNaOH}$, and $92.0 \mathrm{~g} / \mathrm{g}$ for $\mathrm{CPNaClO}_{2}$. This sorption capacity is much higher than those reported for other plant fibers in the literature. In the layer system (Table 2), the absorption percentages exceeded $67 \%$ of the maximum absorption capacity in the first five minutes for all fibers. In addition, all fibers reached at least $90 \%$ of their 24-hour sorption capacity in just $60 \mathrm{~min}$. In cases of oil spills, the less time the authorities spend cleaning/removing contaminants, the lower the impact generated on the environment. As observed, the contact time of 60 min presented approximately $90 \%$ of the maximum sorption capacity obtained after 1440 min. Only $\mathrm{CPNaClO}_{2}$ presented $89 \%$ of the maximum capacity after $60 \mathrm{~min}$. Thus, the fibers are more efficient in the contact time of $60 \mathrm{~min}$, in cases of real environmental accidents. Thus, considering the influence of the oil characteristics in the absorption capacity, diesel, marine diesel, new and used engine lubricant as well as benzene were evaluated in the absorption capacity test using the fibers $\mathrm{CP}, \mathrm{CPHT}, \mathrm{CPNaOH}$, and $\mathrm{CPNaClO}_{2}$ for a contact time of $1440 \mathrm{~min}$ and dry system. Table 3 listed the proprieties of oil and organic solvent. 
Table 3. Properties of the Oils and the Organic Solvents

\begin{tabular}{|c|c|c|}
\hline Sample & Density at $20^{\circ} \mathrm{C}\left(\mathrm{kg} / \mathrm{m}^{3}\right)$ & Viscosity $(\mathrm{cP})$ \\
\hline Diesel & 813 & 1.953 \\
\hline Marine Diesel & 825 & 2.375 \\
\hline New engine lubricant & 850 & 62.73 \\
\hline Used engine lubricant & 854 & 69.25 \\
\hline Benzene & 808 & 0.484 \\
\hline Crude oil & 861 & 73.60 \\
\hline
\end{tabular}

The results are presented in Fig. 4a. In the dry test of CPHT fibers, $\mathrm{CPNaOH}$ and $\mathrm{CPNaClO}_{2}$ had absorption capacities greater than $\mathrm{CP}$ for all oils and solvent that were tested. Karan et al. (2011) presented in their studies the viscosity of the oil as a parameter of great importance in the sorption process. In general, an increase in the viscosity of the oil reduces the sorption within the pores and capillary vessels, but on the other hand, more viscous oils have higher sorption due to adhesion to the surfaces of the materials. Therefore, Fig. $4 \mathrm{~b}$ confirms a lower absorption capacity for diesel, marine diesel, and benzene when compared to lubricating oils and crude oil.

Hilário et al. (2019) demonstrated (CP) that oils are adsorbed by hydrophobic interactions and capillary action forces that penetrate the lumen through the inner capillary. The amount of oil retained within the $\mathrm{CP}$ also depends on the oleophilicity of the fiber and physical characteristics of the oil (Hilário et al. 2019).

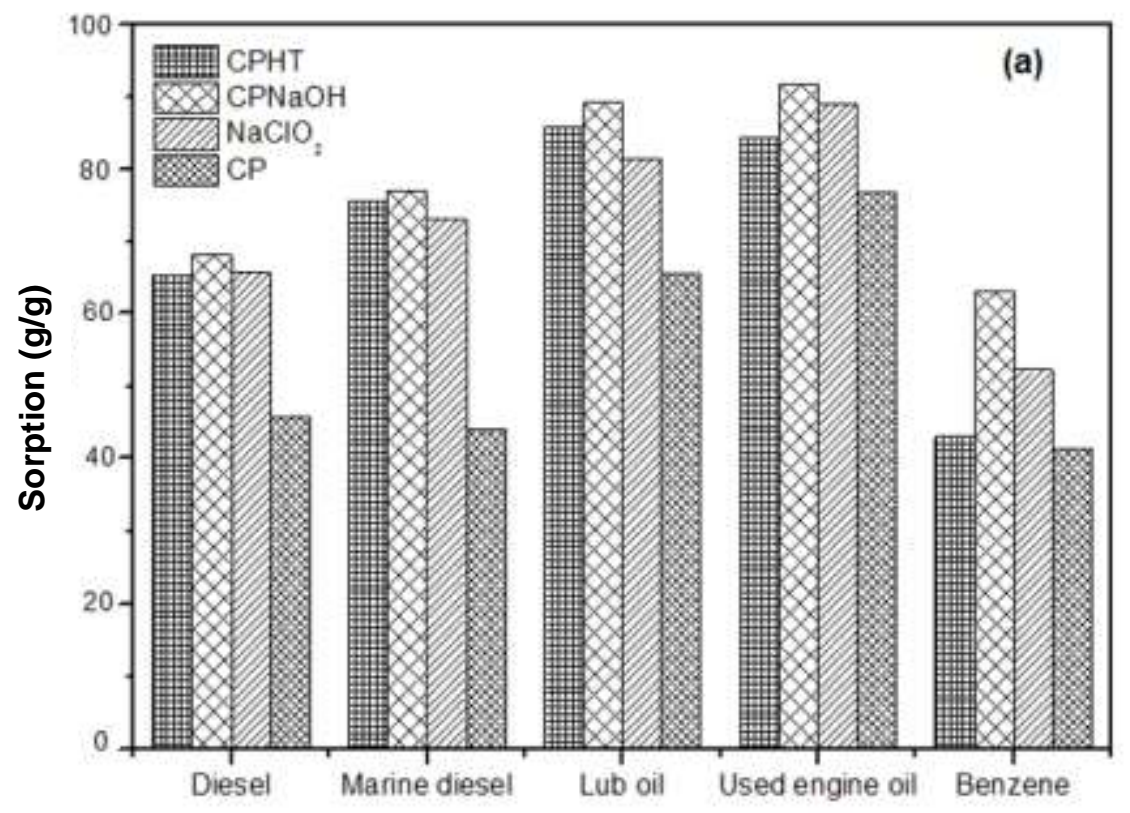




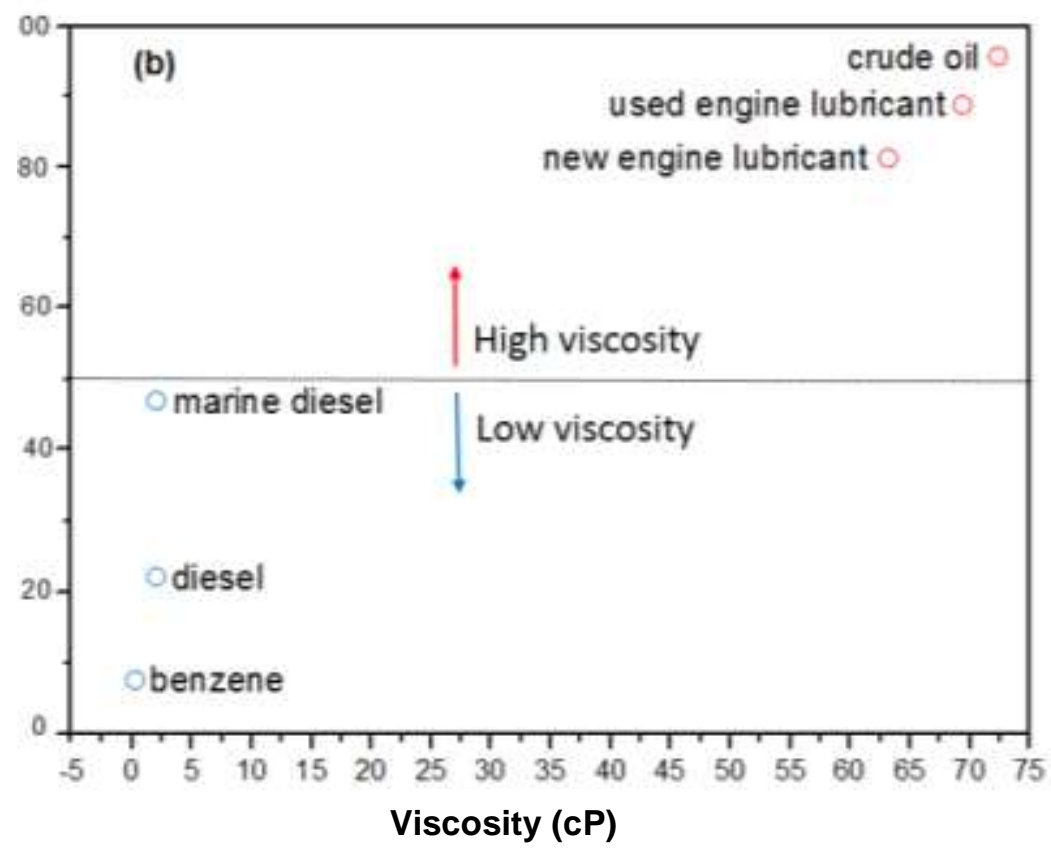

Fig. 4. Dry oil absorption test (a) comparing $\mathrm{CP}$ with $\mathrm{CPHT}, \mathrm{CPNaOH}$, and $\mathrm{CPNaClO}_{2}$ for a contact time of $1440 \mathrm{~min}$, and (b) effect of viscosity in absorption for different oils and organic solvent for a contact time of $1440 \mathrm{~min}$

In addition to the high oil absorption capacity and fast absorption, good reuse capacity is also necessary for the development of an excellent oil sorbent. Thus, to evaluate the reuse capacity of $\mathrm{CP}, \mathrm{CPHT}, \mathrm{CPNaOH}$, and $\mathrm{CPNaClO}_{2}$ fibers, simple compression was used during 6 cycles; the results are shown in Fig. 5. After the first recycle test, the $\mathrm{CP}$, $\mathrm{CPHT}, \mathrm{CPNaOH}$, and $\mathrm{CPNaClO}_{2}$ resorption was about $82 \%, 85 \%, 83 \%$, and $89 \%$ of crude oil, demonstrating that fibers can be well reused for another oil absorption test.

The average resorption capacity of fibers after 6 cycles was above $50 \%$ of oil when compared to the initial absorption. A mass total of $445.8 \mathrm{~g}$ of crude oil per gram of $\mathrm{CPNaOH}$ fiber was removed after 6 resorption cycles, demonstrating that the treated fiber has a reuse potential. 


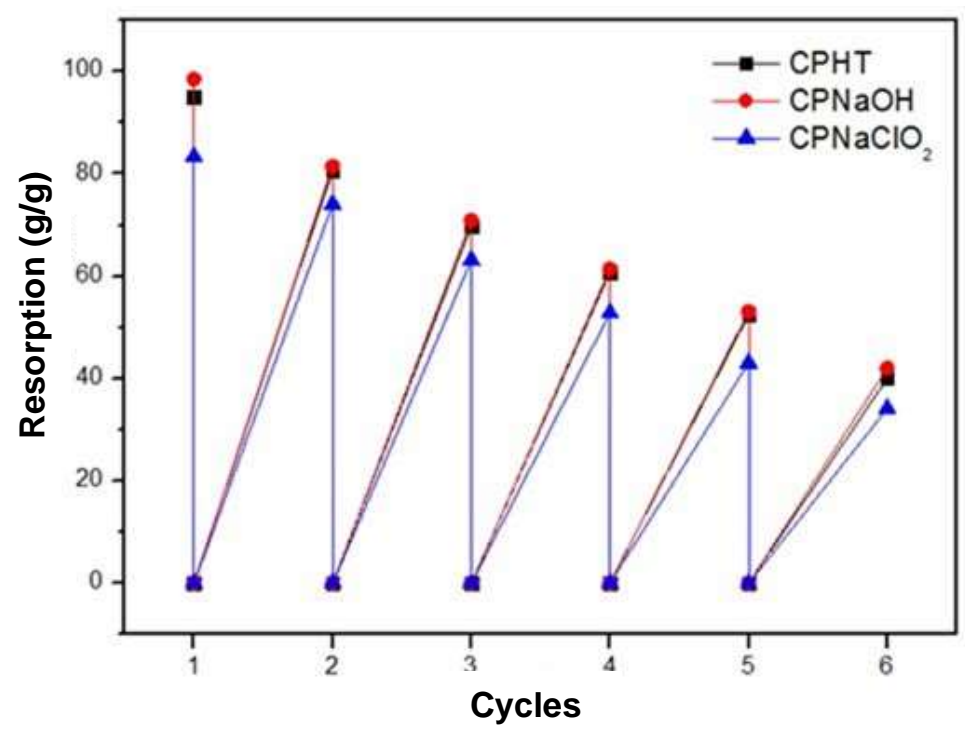

Fig. 5. Resorption test for the crude oil using fibers $\mathrm{CP}, \mathrm{CPHT}, \mathrm{CPNaOH}$, and $\mathrm{CPNaClO} 2$

\section{Wettability}

Figure 6 displays the record of the selectivity test using $\mathrm{CPNaOH}$ fiber. The fiber wettability was verified by the contact angle between the surface of the fiber with water or diesel drop, to confirm the hydrophilic and hydrophobic properties. As shown in Fig.s 6a$\mathrm{b}$, the contact angle was visible on the surface of $\mathrm{CPNaOH}$, and the contact angles $(\theta)$ were $0^{\circ}$ and $114^{\circ}$, for diesel and water, respectively. These results demonstrated hydrophobicity and oleophobicity.

The wettability test was also recorded with the aid of a digital camera. The $\mathrm{CPNaOH}$ was placed on a glass plate, and about $2 \mu \mathrm{L}$ of diesel or distilled water with methyl blue dye was dropped using a microsyringe (Fig. 6a-b). When diesel came into contact with $\mathrm{CPNaOH}$, it was fully absorbed (Fig. 6b), while the distilled water was free on the fiber surface formed spherical drops (Fig. 6a).

The CPHT and $\mathrm{CPNaClO}_{2}$ contact angles were $121^{\circ}$ and $119^{\circ}$. There was a greater decrease in the water contact angle for $\mathrm{CPNaOH}$. This was a consequence of alkali treatment and, possibly, a greater reduction in the waxy surface of the fibers, also evidenced by the infrared spectra (Fig. 2) due to the decrease in the intensity at $2920 \mathrm{~cm}^{-1}$ that is associated to the $\mathrm{CH}$ stretch, and in the water sorption test (Fig. 3c).

The fiber was taped to the bottom of a $100 \mathrm{~mL}$ glass beaker with double-sided tape to evaluate the selectivity of $\mathrm{CPNaOH}$. When water was added (Fig. 6c-d), a silver reflex appeared on the surfaces of the fibers. This phenomenon is attributed to the presence of a thin air layer, which can form a reflection on the surfaces of the fiber (Fig. 6b) (Zheng et al. 2017). The same procedure was performed with diesel oil, where the swelling of $\mathrm{CPNaOH}$ was observed when the diesel oil was absorbed, showing selectivity to oil (Fig. 6e). 
Table 4. Absorption Percentage for the Several Contact Times in Relation to the Time 1140 min for the Dry and Layer Systems

\begin{tabular}{|c|c|c|c|c|}
\hline $\begin{array}{l}\text { Sorbent } \\
\text { Material }\end{array}$ & Treatment & $\begin{array}{c}\text { Sorption } \\
\text { capacity }(\mathrm{g} / \mathrm{g}) \\
\end{array}$ & Oil & Reference \\
\hline Kapok fiber & $\begin{array}{c}\text { In natura } \\
\text { Water } \\
\mathrm{NaOH} \\
\mathrm{HCl} \\
\mathrm{NaClO}_{2} \\
\text { Chloroform }\end{array}$ & $\begin{array}{l}30 \\
34 \\
32 \\
35 \\
24\end{array}$ & Toluene & $\begin{array}{c}\text { Wang et al. } \\
2012\end{array}$ \\
\hline Kapok Fiber & Packed & $\begin{array}{l}36 \\
43 \\
45 \\
\end{array}$ & $\begin{array}{c}\text { Diesel } \\
\text { Hydraulic oil } \\
\text { Motor oil }\end{array}$ & $\begin{array}{c}\text { Lim and } \\
\text { Hung 2007a }\end{array}$ \\
\hline \multirow{3}{*}{$\begin{array}{c}\text { Calotropis } \\
\text { gigantea fiber }\end{array}$} & $\begin{array}{c}\text { Nickel } \\
\text { Copper }\end{array}$ & $\begin{array}{l}45 \text { to } 120 \\
45 \text { to } 105\end{array}$ & $\begin{array}{l}\text { Oil and organic } \\
\text { solvents }\end{array}$ & $\begin{array}{l}\text { Cao et al. } \\
2018\end{array}$ \\
\hline & $\begin{array}{c}\text { In natura } \\
\mathrm{NaClO}_{2}+ \\
\text { Carbonized }\end{array}$ & $\begin{array}{l}60.59 \\
84.71\end{array}$ & Kerosene & $\begin{array}{c}\text { Tu et al. } \\
2018\end{array}$ \\
\hline & In natura & 22.6 to 47.6 & $\begin{array}{c}\text { Oil and organic } \\
\text { solvents }\end{array}$ & $\begin{array}{c}\text { Zheng et al. } \\
2016\end{array}$ \\
\hline \multirow{2}{*}{ Barley straw } & Pyrolyzed & $\begin{array}{l}5.9 \text { to } 7.6 \\
8.1 \text { to } 9.2\end{array}$ & $\begin{array}{l}\text { Diesel } \\
\text { Heavy oil }\end{array}$ & $\begin{array}{c}\text { Husseien et } \\
\text { al. } 2008\end{array}$ \\
\hline & Surfactant-modified & $\begin{array}{l}30 \text { to } 90 \\
15 \text { to } 95\end{array}$ & $\begin{array}{l}\text { Canola oil } \\
\text { Mineral oil }\end{array}$ & $\begin{array}{c}\text { Ibrahim et al. } \\
2009\end{array}$ \\
\hline $\begin{array}{c}\text { Silkworm } \\
\text { cocoon }\end{array}$ & Cocoon residues & $\begin{array}{l}42 \text { to } 52 \\
37 \text { to } 60 \\
\end{array}$ & $\begin{array}{c}\text { Motor oil } \\
\text { Vegetable }\end{array}$ & $\begin{array}{l}\text { Moriwaki et } \\
\text { al. 2009] }\end{array}$ \\
\hline Cotton fiber & $\begin{array}{c}\text { Loose fiber } \\
\text { Fiber pad shape }\end{array}$ & $\begin{array}{c}22.5 \\
18.43 \\
\end{array}$ & Lubricating oil & $\begin{array}{c}\text { Husseien et } \\
\text { al. } 2011\end{array}$ \\
\hline \multirow{2}{*}{ Peat } & Graft add-on & $\begin{array}{l}36.60 \\
25.56 \\
\end{array}$ & $\begin{array}{c}\text { Crude oil } \\
\text { Vegetable oil }\end{array}$ & $\begin{array}{l}\text { AlAmeri et } \\
\text { al. } 2019\end{array}$ \\
\hline & Granular & 9 to 12 & Diesel & $\begin{array}{c}\text { Cojocaru et } \\
\text { al. } 2011\end{array}$ \\
\hline Populus fiber & $\begin{array}{c}\text { Hydrothermal } \\
\text { Acetylation }\end{array}$ & $\begin{array}{l}16.78 \\
21.57 \\
\end{array}$ & Corn oil & $\begin{array}{c}\text { Zhang et al. } \\
2014\end{array}$ \\
\hline $\begin{array}{c}\text { Celulose } \\
\text { aerogel }\end{array}$ & Methyltrimetoxissyan & 40 to 95 & Oil & $\begin{array}{l}\text { Feng et al. } \\
2015\end{array}$ \\
\hline $\begin{array}{l}\text { Ganoderma } \\
\text { applanatum } \\
\text { mushroom }\end{array}$ & PFOCTS* & 1.8 to 3.1 & Oil & $\begin{array}{l}\text { Balzamo et } \\
\text { al. } 2019\end{array}$ \\
\hline $\begin{array}{c}\text { Hybrid of } \\
\text { cotton, } \\
\text { Kapok, } \\
\text { Asclepias } \\
\text { Syriaca, } \\
\text { Calotropis } \\
\text { procera, } \\
\text { Calotropis } \\
\text { gigantea } \\
\text { Polypropylene }\end{array}$ & Hybrid & $\begin{array}{l}40.16 \\
23.00\end{array}$ & $\begin{array}{l}\text { Heavy oil } \\
\text { Diesel }\end{array}$ & $\begin{array}{l}\text { Thilagavathi } \\
\text { et al. } 2018\end{array}$ \\
\hline \multirow{2}{*}{$\begin{array}{l}\text { Calotropis } \\
\text { procera }\end{array}$} & $\begin{array}{l}\text { In natura } \\
\text { Thermal }\end{array}$ & $\begin{array}{c}74.04 \\
94.31 \text { to } 124.60\end{array}$ & Crude oil & $\begin{array}{c}\text { Hilário et al. } \\
2019 \\
\end{array}$ \\
\hline & $\begin{array}{c}\text { Hydrothermal } \\
\mathrm{NaOH} \\
\mathrm{NaClO}_{2}\end{array}$ & $\begin{array}{c}99.20 \\
103.90 \\
92.04\end{array}$ & Crude oil & $\begin{array}{c}\text { This } \\
\text { Research }\end{array}$ \\
\hline
\end{tabular}




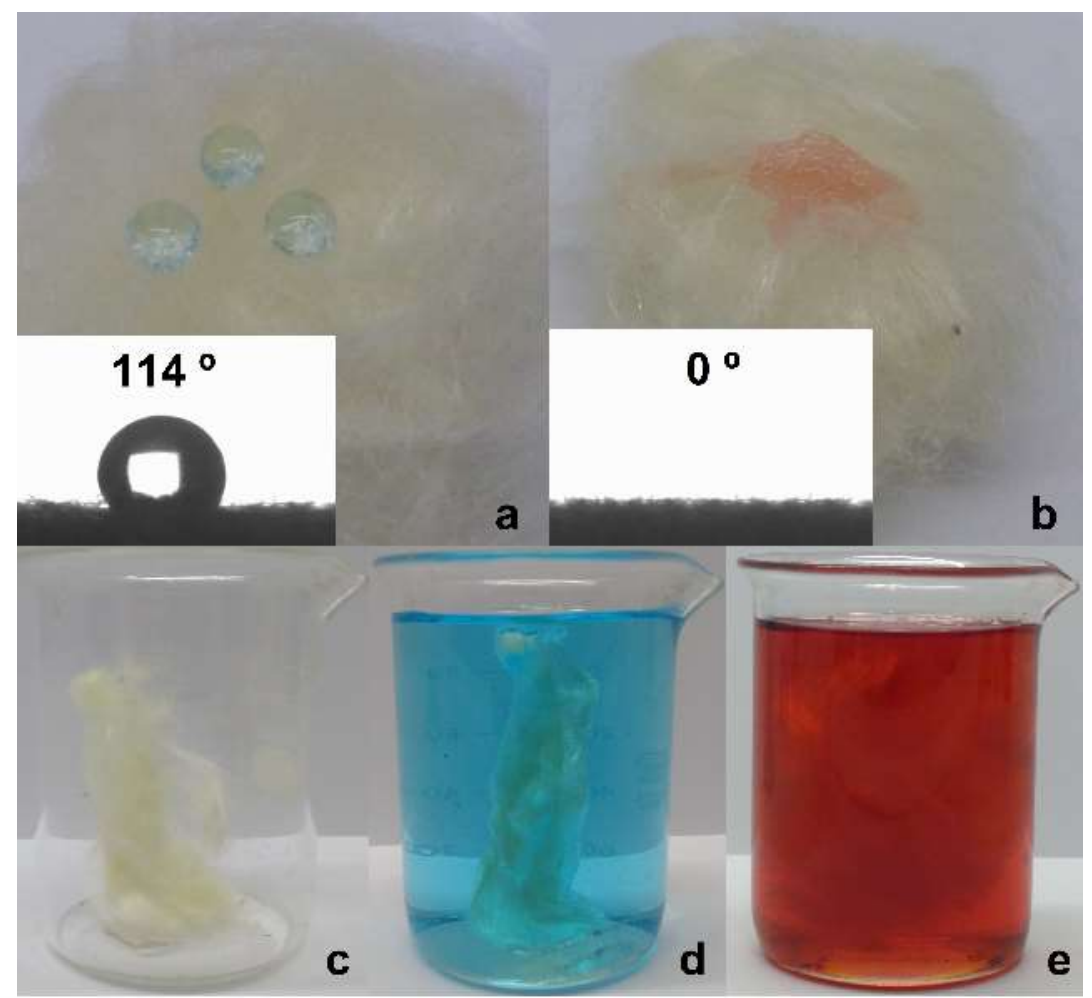

Fig. 6. Digital images of the wettability and selectivity test: (a) water (b) diesel oil; Selectivity essay: (c) $\mathrm{CPNaOH}$, (d) $\mathrm{CPNaOH}$ immersed in water, and (e) $\mathrm{CPNaOH}$ immersed in diesel oil

\section{Advantages of treated Calotropis process over other materials}

In general, the absorption capacity of crude oil by the Calotropis procera fiber treated with solutions was equal and even higher than those presented by most sorbents reported in dry tests. Table 4 presents the sorption capacity of organic oils and solvents for various sorbent materials that have suffered modification processes to obtain better results. The CP treated with $\mathrm{NaOH}, \mathrm{NaClO}_{2}$, and hydrothermally presented a high absorption capacity for the crude oil used in this work. One can observe that some materials have higher absorption capacity, such as the thermally treated CP fiber (Hilário et al. 2019). The treatment with $\mathrm{NaOH}$ significantly increased the internal diameter and surface area of the $\mathrm{CP}$ lumens, allowing the increase of absorption capacity, being a promising alternative against synthetic oil absorbers traditionally applied in the oil spill cleaning process.

\section{CONCLUSIONS}

1. Calotropis procera $(\mathrm{CP})$ fibers that had been either hydrothermally treated (CPHT), treated with $0.1 \% \mathrm{NaOH}(\mathrm{CPNaOH})$, or treated with $1 \% \mathrm{NaClO}_{2}\left(\mathrm{CPNaClO}_{2}\right)$ presented high hydrophobicity, oleophobicity, and selectivity for oil, which was confirmed by contact angles of predominantly hydrophobic surfaces, $\theta$ of $121^{\circ}, 119^{\circ}$, $114^{\circ}$ in water, and $0^{\circ}$ for diesel oil.

2. FTIR spectra pointed out that after treatments of fibers in solution $(\mathrm{CPHT}, \mathrm{CPNaOH}$, and $\mathrm{CPNaClO}_{2}$ ), there was a decrease and disappearance of some peaks, which may be correlated with partial removal of the wax. 
3. Micrographs obtained by SEM-FEG equipment revealed the surface morphology of the $\mathrm{CP}, \mathrm{CPHT}, \mathrm{CPNaOH}$, and $\mathrm{CPNaClO}_{2}$ and showed the presence of hollow structures, wherein the lumens contribute significantly to oil fixation. However, at the end of treatment in solution, sorption was observed the increase within the cell walls and empty spaces (lumens), increasing the oil absorption potential of the fibers.

4. In the dry system absorption test, the fibers treated with the solutions showed an increase in oil absorption from $21.7 \%$ to $32.2 \%$ when compared with untreated CP.

5. Tests carried out with a of oil on water showed the general absorption profile, $\mathrm{CPNaClO}_{2}<\mathrm{CPHT}<\mathrm{CPNaOH}$, with maximum sorption capacities of 92.0, 99.2, and $103.9 \mathrm{~g} / \mathrm{g}$.

6. It was also observed that in the contact time of $5 \mathrm{~min}$ in the dry and layer system, the absorption values of the fibers had exceeded $65 \%$ and $67 \%$, respectively. After 60 min of exposure, the absorption of most fibers in both systems exceeded $90 \%$ of their absorption capacity for the contact time of $1440 \mathrm{~min}$.

7. Based on this work, the $\mathrm{CP}, \mathrm{CPHT}, \mathrm{CPNaOH}$, and $\mathrm{CPNaClO}_{2}$ fibers can be used as a successful alternative for cleaning and removing crude oil and petroleum derivatives from leaks and spills, once that it has an excellent selectivity water/oil, high availability, reuse capacity, and high oil absorption.

\section{ACKNOWLEDGMENTS}

The authors acknowledge the Coordination for the Improvement of Higher Education Personnel CAPES, the Federal University of Rio Grande do Norte and the Nucleus of Primary Processing and Reuse of Produced Water and Waste for financial support.

\section{REFERENCES CITED}

Abdullah, M. A., Rahmah, A. U., and Man, Z. (2010). "Physicochemical and sorption characteristics of Malaysian Ceiba pentandra (L.) Gaertn. as a natural oil sorbent," J. Hazard. Mater. 177(1-3), 683-691. DOI: 10.1016/j.jhazmat.2009.12.085

Adebajo, M. O., and Frost, R. L. (2004). "Acetylation of raw cotton for oil spill cleanup application: An FTIR and 13C MAS NMR spectroscopic investigation," Spectrochim. Acta A. 60(10), 2315-2321. DOI: 10.1016 / j.saa.2003.12.005

AlAmeri, K., Giwa, A., Yousef, L., Alraeesi, A., and Taher, H. (2019). "Sorption and removal of crude oil spills from seawater using peat-derived biochar: An optimization study," J. Environ. Manage. 250, 109465. DOI: 10.1016/j.jenvman.2019.109465

Annunciado, T. R., Sydenstricker, T. H. D., and Amico, S. C. (2005). "Experimental investigation of various vegetable fibers as sorbent materials for oil spills," Mar. Pollut. Bull. 50(11), 1340-1346. DOI: 10.1016/j.marpolbul.2005.04.043

Anužyte, E. and Vaišis, V. (2018). "Natural oil sorbents modification methods for hydrophobicity improvement," Energy. Proced. 147, 295-300. DOI: 10.3846 / aainz.2018.005

Balzamo, G., Singh, N., Wang, N., Vladisavljević, G. T., Bolognesi, G., and Mele, E. 
(2019). "3D arrays of super-hydrophobic microtubes from polypore mushrooms as naturally-derived systems for oil absorption," Materials 12(1), 132. DOI: 10.3390/ma12010132

Bastani, D., Safekordi, A., Alihosseini, A., and Taghikhani, V. (2006). "Study of oil sorption by expanded perlite at 298.15 K," Sep. Purif. Technol. 52(2), 295-300. DOI: 10.1016/j.seppur.2006.05.004

Cao, E., Xiao, W., Duan, W., Wang, N., Wang, A., and Zheng, Y. (2018). "Metallic nanoparticles roughened Calotropis gigantea fiber enables efficient absorption of oils and organic solvents," Ind. Crop. Prod. 115, 272-279. DOI:

10.1016/j.indcrop.2018.02.052

Cojocaru, C., Macoveanu, M., and Cretescu, I. (2011). 'Peat-based sorbents for the removal of oil spills from water surface: Application of artificial neural network modeling," Colloids Surf. A. 384(1-3), 675-684. DOI:

10.1016/j.colsurfa.2011.05.036

Draman, S. F. S., Daik, R., Latif, F. A., and El-Sheikh, S. M. (2014). "Characterization and thermal decomposition kinetics of kapok (Ceiba pentandra L.)-based cellulose," BioResources 9(1), 8-23. DOI: 10.15376/biores.9.1.8-23

Fan, M., Dai, D., and Huang, B. (2012). "Fourier transform infrared spectroscopy for natural fibres," in: Fourier Transform - Materials Analysis, S. Salih (ed.), Intech, Rijeka, Croatia, pp. 45-69.

Feng, J., Nguyen, S. T., Fan, Z., and Duong, H. M. (2015). "Advanced fabrication and oil absorption properties of super-hydrophobic recycled cellulose aerogels," Chem. Eng.. J. 270, 168-175. DOI: 10.1016/j.cej.2015.02.034

Ge, J., Zhao, H. Y., Zhu, H. W., Huang, J., Shi, L. A., and Yu, S. H. (2016). "Advanced sorbents for oil-spill cleanup: Recent advances and future perspectives," Adv. Mater. 28(47),10459-10490. DOI: 10.1002/adma.201601812

Gros, J., Nabi, D., Würz, B., Wick, L. Y., Brussaard, C. P., Huisman, J., van der Meer, J.R., Reddy, C. M., and Arey, J. S. (2014). "First day of an oil spill on the open sea: early mass transfers of hydrocarbons to air and water," Environ. Sci. Technol. 48(16), 9400-9411. DOI: 10.1021/es502437e

Hilário, L. S., Anjos, R. B., Juviniano, H. B. M., and Silva, D. R. (2019). "Evaluation of thermally treated Calotropis Procera fiber for the removal of crude oil on the water surface," Materials 12(23), 3894. DOI: 10.3390/ma12233894

Huang, X. and Lim, T.T. (2006). "Performance and mechanism of a hydrophobicoleophilic kapok filter for oil/water separation,” Desalination 190(1-3), 295-307. DOI: 10.1016/j.desal.2005.09.009

Hubbe, M. A., Rojas, O. J., Fingas, M., and Gupta, B. S. (2013). "Cellulosic substrates for removal of pollutants from aqueous systems: A Review. 3. Spilled oil and emulsified organic liquids," BioResources 8(2), 3038-3097. DOI:

10.15376/biores.8.2.3038-3097

Husseien, M., Amer, A. A., El-Maghraby, A., and Taha, N.A. (2008). "Experimental investigation of thermal modification influence on sorption qualities of barley straw," J. Appl. Sci. Res. 4(6), 652-657.

Husseien , M., Amer, A. A., and Sawsan, I. I. (2011). "Heavy oil spill cleanup using law grade raw cotton fibers: trial for practical application," J. Pet. Technol. Altern. Fuels 2(8), 132-140.

Ibrahim, S., Ang, H. M., and Wang, S. (2009). "Removal of emulsified food and mineral 
oils from wastewater using surfactant modified barley straw," Bioresour. Technol. 100(23), 5744-5749. DOI: 10.1016/j.biortech.2009.06.070

Karan, C. P., Rengasamy, R. S., and Das, D. (2011). "Oil spill cleanup by structured fibre assembly," Indian J. Fibre Text. Res.. 36(2), 190-200.

Ke, Q., Jin, Y., Jiang, P., and Yu, J. (2014). "Oil/water separation performances of superhydrophobic and superoleophilic sponges," Langmuir 30(44), 13137-13142. DOI: $10.1021 / 1 \mathrm{a} 502521 \mathrm{c}$

Lim, T. T., and Huang, X. (2007a). "Evaluation of hydrophobicity/oleophilicity of kapok andits performance in oily water filtration: Comparison of raw and solvent-treated fibers," Ind. Crop. Prod. 26(2), 125-134. DOI: 10.1016/j.indcrop.2007.02.007

Lim, T., and Huang, X. (2007b). "Evaluation of kapok (Ceiba pentandra (L.) Gaertn.) as anatural hollow hydrophobic-oleophilic fibrous sorbent for oil spill cleanup," Chemosphere 66(5), 955-963. DOI: 10.1016/j.chemosphere.2006.05.062

Liu, J., and Wang, F. (2011). "Influence of mercerization on microstructure and properties of kapok blended yarns with different blending ratios," J. Eng. Fiber Fabr. 6(3), 63-68. DOI: 10.1177/155892501100600308.

Liu, Y., Wang, J. T., Zheng, Y. A., and Wang, A. Q. (2012). “Adsorption of methylene blue by kapok fiber treated by sodium chlorite optimized with response surface methodology," Chem. Eng. J. 184, 248-255. DOI: 10.1016/j.cej.2012.01.049

Lv, E., Xia, W., Tang, M., and Pu, Y. (2016). "Preparation of an efficient oil-spill adsorbent based on wheat straw," BioResources 12, 296-315. DOI: 10.15376/biores.12.1.296-315

Ma, Q., Cheng, H., Fane, A. G., Wang, R., and Zhang, H. (2016). "Recent development of advanced materials with special wettability for selective oil/water separation," Small 12(16), 2186-2202. DOI: 10.1002/smll.201503685

Moriwaki, H., Kitajima, S., Kurashima, M., Hagiwara, A., Haraguchi, K., Shirai, K., Kanekatsu, R., and Kiguchi, K. (2009). "Utilization of silkworm cocoon waste as a sorbent for the removal of oil from water," J. Hazard. Mater. 165(1-3), 266-270. DOI: 10.1016/j.jhazmat.2008.09.116

Mwaikambo, L. Y., and Ansell, M. P. (2002). "Chemical modification of hemp, sisal, jute and kapok fibers by alkalization," J. Appl. Polym. Sci. 84(12), 2222-2234. DOI: 10.1002/app.10460.

Mysore, D., Viraraghavan, T., and Jin, Y.-C. (2005). "Treatment of oily waters using vermiculite," Water Res. 39(12), 2643-2653. DOI: 10.1016/j.watres.2005.04.034

Nascimento, J. H. O., Coelho, M. P. G., Silva, A. P., Silva, K. K. O. S., dos Santos, A. R. L., Campos, C. F., Morais, J. P. S., and Sivam, R. L. (2016). "Removal of crude oil using a new natural fibre-Calotropis procera," in: Natural Fibres: Advances in Science and Technology Towards Industrial Applications, Fangueiro, R., Rana, S. (eds.) SpringerNature, Dordrecht, Netherlands, pp. 113-127.

Paul, J. H., Hollander, D., Coble, P., Daly, K. L., Murasko, S., English, D., Basso, J., Delaney, J., McDaniel, L., and Kovach, C. W. (2013). "Toxicity and mutagenicity of gulf of mexico waters during and after the deepwater horizon oil spill," Environ. Sci. Technol. 47(17), 9651-9659. DOI: 10.1021/es401761h

Pintor, A. M. A., Vilar, V. J. P., Botelho, C. M. S., and Boaventura, R. A. R. (2016). "Oil and grease removal from wastewaters: sorption treatment as an alternative to state-ofthe-art technologies. A critical review," Chem. Eng. J. 297, 229-255. DOI: 10.1016/j.cej.2016.03.121. 
Prince, R. C. (2015). “Oil spill dispersants: boon or bane?," Environ. Sci. Technol. 49(11), 6376-6384. DOI: 10.1021/acs.est.5b00961

Razavi, Z., Mirghaffari, N., and Rezaei, B. (2015). "Performance comparison of raw and thermal modified rice husk for decontamination of oil polluted water," Clean-Soil Air Water 43(2), 182-190. DOI: 10.1002/clen.201300753

Rengasamy, R. S., Das, D., and Praba Karan, C. (2011). "Study of oil sorption behavior of filled and structured fiber assemblies made from polypropylene, kapok and milkweed fibers," J. Hazard. Mater. 186(1), 526-532. DOI: 10.1016/j.jhazmat.2010.11.031

Renuka, S., Rengasamy, R. S., and Das, D. (2015). "Studies on needle-punched natural and polypropylene fiber nonwovens as oil sorbents." J. Ind. Text. 46(4), 1121-1143. DOI: $10.1177 / 1528083715613630$

Sabir, S. (2015). "Approach of cost-effective adsorbents for oil removal from oily water," Crit. Rev. Env. Sci. Tec. 45(17), 1916-1945. DOI: 10.1080/10643389.2014.1001143.

Saleem, J., Adil Riaz, M., and Gordon, M. (2018). "Oil sorbents from plastic wastes and polymers: a review," J. Hazard. Mater. 341, 424-437. DOI:

10.1016/j.jhazmat.2017.07.072

Selvam, P. V. P., and Santiago, B. H. (2007). "Tratamento superficial da fibra do coco: estudo de caso baseado numa alternativa econômica para fabricação de materiais compósitos," Revista Analytica, 2007(26), 783-788.

Song, K., Zhu, X., Zhu, W., and Li, X. (2019). "Preparation and characterization of cellulose nanocrystal extracted from Calotropis procera biomass," Bioresour. Bioprocess. 6(1), 1-8. DOI: 10.1186/s40643-019-0279-z

Tang, A. M., Hu, T. T., and Su, X., (2012). "The influence of pretreatment on kapok fiber/CdS nanocomposites morphology structure by AFM," Funct. Mater. 43(24), 3437-3441.

Thilagavathi, G., Praba Karan, C., and Das, D. (2018). “Oil sorption and retention capacities of thermally-bonded hybrid nonwovens prepared from cotton, kapok, milkweed and polypropylene fibers," J. Environ. Manage. 219, 340-349. DOI: 10.1016 / j.jenvman.2018.04.107

Tu, L., Duan, W., Xiao, W., Fu, C., Wang, A., and Zheng, Y. (2018). “Calotropis gigantea fiber derived carbon fiber enables fast and efficient absorption of oils and organic solvents. Sep Purif Technol. 192, 30-35. DOI: 10.1016/j.seppur.2017.10.005

van Gelderen, L., Malmquist, L. M., and Jomass, G. (2017). "Vaporization order and burning efficiency of crude oils during in-situ burning on water," Fuel 191, 528-537. DOI: 10.1016/j.fuel.2016.11.109

Wahi, R., Chuah, L. A., Choong, T. S. Y., Ngaini, Z., and Nourouzi, M. M. (2014). “Oil removal from aqueous state by natural fibrous sorbent: An overview. Sep. Purif. Technol. 113, 51-63. DOI: 10.1016/j.seppur.2013.04.015

Wang, J., Zheng, Y., and Wang, A. (2012). "Effect of kapok fiber treated with various solvents on oil absorbency," Ind. Crop. Prod. 40, 178-184. DOI:

10.1016/j.indcrop.2012.03.002

Wang, J., Zheng, Y., Kang, Y., and Wang, A., (2013a). "Investigation of oil sorptioncapability of PBMA/SiO 2 coated kapok fiber," Chem. Eng. J. 223, 632-637. DOI: 10.1016/j.cej.2013.03.007

Wang, J., Zheng, Y., and Wang, A. (2013b). "Coated kapok fiber for removal of spilled oil,” Mar. Pollut. Bull., 69(1-2), 91-96. DOI: 10.1016/j.marpolbul.2013.01.007 
Wang, J. T., Zheng, Y. A., Wang, and A. Q. (2013c). "Investigation of acetylated kapok fibers on the sorption of oil in water," J. Environ. Sci. 25(2), 246-253. DOI: 10.1016/S1001-0742(12)60031-X.

Wu, L., Li, L., Li, B., Zhang, J., and Wang, A. (2015). "Magnetic, durable, and superhydrophobic polyurethane@ $\mathrm{Fe}_{3} \mathrm{O}_{4} @ \mathrm{SiO}_{2} @$ fluoropolymer sponges for selective oil absorption and oil/water separation," ACS Appl. Mater. Interfaces 7(8), 49364946. DOI: $10.1021 / \mathrm{am} 5091353$

Yi, L., Liang, G., Xiao, W., Duan, W., Wang, A., and Zheng, Y. (2018). "Rapid nitrogenrich modification of Calotropis gigantea fiber for highly efficient removal of fluoroquinolone antibiotics," J. Mol. Liq. 256, 408-415. DOI: 10.1016/j.molliq.2018.02.060

Yu, L., Hao, G., Xiao, L., Yin, Q., Xia, M., and Jiang, W. (2017). "Robust magnetic polystyrene foam for high efficiency and removal oil from water surface," Sep. Purif. Technol. 173, 121-128. DOI: 10.1016/j.seppur.2016.09.022

Zadaka-Amir, D., Bleiman. N., and Mishael, Y. G. (2013). "Sepiolite as an effective natural porous adsorbent for surface oil-spill." Micropor. Mesopor. Mat. 169, 153159. DOI: 10.1016/j.micromeso.2012.11.002

Zengel, S., Montague, C. L., Pennings, S. C., Powers, S. P., Steinhoff, M., Fricano, G., Schlemme, C., Zhang, M., Oehrig, J., Nixon, Z., Rouhani, S., and Michel, J. (2016). "Impacts of the Deepwater Horizon oil spill on salt marsh periwinkles (Littoraria irrorata)," Environ.Sci. Technol. 50(2), 643-652. DOI: 10.1021/acs.est.5b04371

Zhang, Y., Yang, S., Wu, J. -Q., Yuan, T. -Q., Sun, R. -C. (2014). "Preparation and characterization of lignocellulosic oil sorbent by hydrothermal treatment of Populus fiber," Materials 7(9), 6733-6747. DOI: 10.3390/ma7096733

Zheng, Y., Cao, E., Zhu, Y., Wang, A., and Hu, H. (2016). "Perfluorosilane treated Calotropis gigantea fiber: Instant hydrophobic-oleophilic surface with efficient oilabsorbing performance," Chem. Eng. J. 295, 477-483. DOI: 10.1016/j.cej.2016.03.074

Zheng, Y., Cao, E., Tu, L., Wang, A., and Hu, H. (2017). “A comparative study for oilabsorbing performance of octadecyltrichlorosilane treated Calotropis gigantea fiber and kapok fiber," Cellulose 24(2), 989-1000. DOI: 10.1007/s10570-016-1155-Z

Zheng, Y., Wang, J., Zhu, Y., and Wang, A. (2015). "Research and application of kapok fiber as an absorbing material: a mini review," J. Environ. Sci-China 27, 21-32. DOI: 10.1016/j.jes.2014.09.026.

Zheng, Y., Zhub, Y. Y., Wang, A., and Hu, H. (2016). "Potential of Calotropis gigantea fiber as an absorbent for removal of oil from water," Ind. Crop. Prod. 83, 387-390. DOI: 10.1016/j.indcrop.2016.01.009

Article submitted: March 12, 2020; Peer review completed: April 26, 2020; Revised version received and accepted: May 14, 2020; Published: May 19, 2020.

DOI: $10.15376 /$ biores. 15.3.5246-5263 